
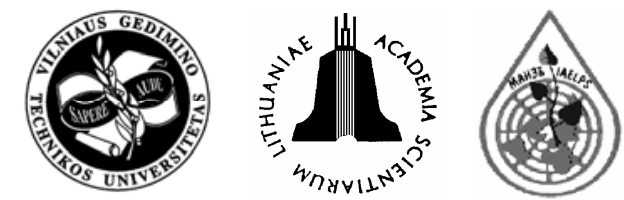

\title{
APPLICATION OF AGRONOMIC PRACTICE IMPROVES PHYTOEXTRACTION ON A MULTIPOLLUTED SITE
}

\author{
Diana Claus ${ }^{1}$, Hernn Dietze ${ }^{2}$, André Gerth ${ }^{3}$, William Grosser ${ }^{4}$, Anja Hebner ${ }^{5}$ \\ ${ }^{1,3,5}$ BioPlanta GmbH, Deutscher Platz 5, D-04103 Leipzig, Germany \\ E-mail: info@bioplanta-leipzig.de \\ ${ }^{2,4}$ Kommunale Wasserwerke Leipzig GmbH, Johannisgasse 7/9, \\ D-04103 Leipzig, Germany. E-mail: info@wasser-leipzig.de
}

Submitted 14 May 2007; accepted 02 Oct 2007

\begin{abstract}
In the context of a joint research project in collaboration with the municipal water works of Leipzig, BioPlanta optimizes the phytoremediation process. This Phytotechnology has been applied since 1996 to a former sewage sludge dewatering plant in Schladitz near Leipzig (Fig 1). At the time of closing in 1990 about 300,000 $\mathrm{m}^{3}$ of heavy metal- and hydrocarbon-contaminated sludge were stored on this site. It is the biggest phytoremediation project of this kind in Europe. An extensive monitoring and analysis program was established to evaluate the progress of the remediation (ending in 2012). Up to now the contamination of the site could be considerably decreased. The removal of heavy metals sums up to several kilograms with an increasing tendency over the last years (Fig 2). The aim of ongoing research activities is to set up improved conditions for an even more efficient extraction of heavy metal ions from contaminated soil and sediments. Optimizing this process should reduce the remediation period by up to two thirds. The technology is to be implemented not only in the Leipzig region but also in future remediation projects.
\end{abstract}

Keywords: phytoremediation, metal bioavailability, chelators, plant selection, crop maintenance, plant biomass.

\section{Introduction}

Metal phytoextraction represents one of the biggest economic opportunities for remediation, based on plants' ability to work as biopumps, extracting and concentrating particular solutes with simultaneous uptake of large amounts of water. It may be applied to metals such as cadmium $(\mathrm{Cd})$, cupper $(\mathrm{Cu})$, chrome $(\mathrm{Cr})$, nickel $(\mathrm{Ni})$, lead $(\mathrm{Pb})$ and zinc $(\mathrm{Zn})$. The amount of metals extracted by plants arises from two factors: (i) the metal concentration in dry plant tissue and (ii) the total biomass of the plant. The product of these factors estimates the total amount of metal extracted from the contaminated soil. Hyperaccumulator plants, for example, are capable of accumulating metals 100 -fold higher ( $2 \%$ on the dry weight basis) than those typically measured in shoots of the common nonaccumulator plants. But most of these species are slowly growing and produce little biomass. This fact limits the use of hyperaccumulator plants for commercial phytoextraction. With highly productive species, the potential for biomass production is about 100 tons of fresh weight per hectare limiting the removal potential to a maximum of $400 \mathrm{~kg}$ metal per hectare and year [1].

Phytoremediation is essentially an agronomic approach and its success depends ultimately on agronomic practices such as plant selection, possibility of cultivation, fertilisation and irrigation. At BioPlanta, research on improving phytoextraction of metal-contaminated sewage sludge has focused mainly on increasing metal transfer from substrate-to-root by changing the chemical environment of the rhizosphere as well as on increasing crop yield of common reed (Phragmites australis) by application of agronomic practices in greenhouse and field studies. With regard to changes of soil conditions during the remediation process (especially soil moisture, humus and clay content, etc.) different plant species have been investigated for cultivation and their potential of metal removal from contaminated sludge.

\section{Materials and methods}

As a basis for determination of experiments the following environmental factors, which may limit the removal of heavy metals by plants, had been defined: (i) soil properties and metal availability, (ii) plant physiology (vitality, stress) and (iii) plant biomass. In addition to extensive field experiments basic investigations were carried out in the greenhouse.

In the context of remediation of metal-contaminated sewage sludge, a surface area of 27,000 square metres was planted with common reed in 1995. Recent field experiments were conducted on subareas. In general, the application of additives such as plant tonics and fertilisers was performed at different points in time within the growing season. Herbicide application to induce stress responds in plants and chelate addition was carried out one-time. Beside common reed, horticultural crops like sunflower (Helianthus annuus), maize (Zea mays) and 
rape (Brassica napus) were planted on this site. In the course of experiments plants were evaluated for their vitality and growth. At different points in time (for common reed) as well as at the end of the vegetation period the aboveground biomass was harvested and dried at $60{ }^{\circ} \mathrm{C}$. The yield of plant biomass per square metre (on fresh and dry weight basis) was calculated.

Greenhouse studies were performed using both pots and site-specific soil columns. Metal-contaminated sewage sludge of the multipolluted site was used as substrate, and common reed was cultivated up to 15 weeks.

The sequential extraction technique described by Tessier et al. [2] was used to determine the amount of metal associated with different soil fractions. The quantitative analysis of $\mathrm{Cd}, \mathrm{Cr}, \mathrm{Cu}, \mathrm{Ni}, \mathrm{Pb}$ and $\mathrm{Zn}$ in both plant and soil matter was performed in the laboratory of the municipal water works of Leipzig using the aqua regia dissolution followed by a chromatographic determination of metals.

\section{Results}

A major factor limiting metal uptake into roots is the slow transport from soil particles to root surfaces. Metals are bound in several soil fractions: (i) in solution as free metal ions and soluble metal complexes; (ii) adsorbed to inorganic soil constituents on ion exchange sites; (iii) precipitated such as oxides, hydroxides, and carbonates; (iv) bound to soil organic matter; and (v) embedded in structures of silicate minerals. In the experiment, only fourteen percent $(860 \mathrm{mg} / \mathrm{kg}$ of dry soil matter) of the total amount of metals present in sewage sludge (mainly $\mathrm{Cd}$, Ni and $\mathrm{Zn}$ ) have been quantified by sequential extraction to be readily available (bioavailable) for plant uptake (Fig 3). Metals like Cr (930 mg/kg), Cu (970 mg/kg) and $\mathrm{Pb}(1,200 \mathrm{mg} / \mathrm{kg})$ predominantly occur in the oxide and organic fraction or as soil precipitate, which are largely unavailable for plant uptake.

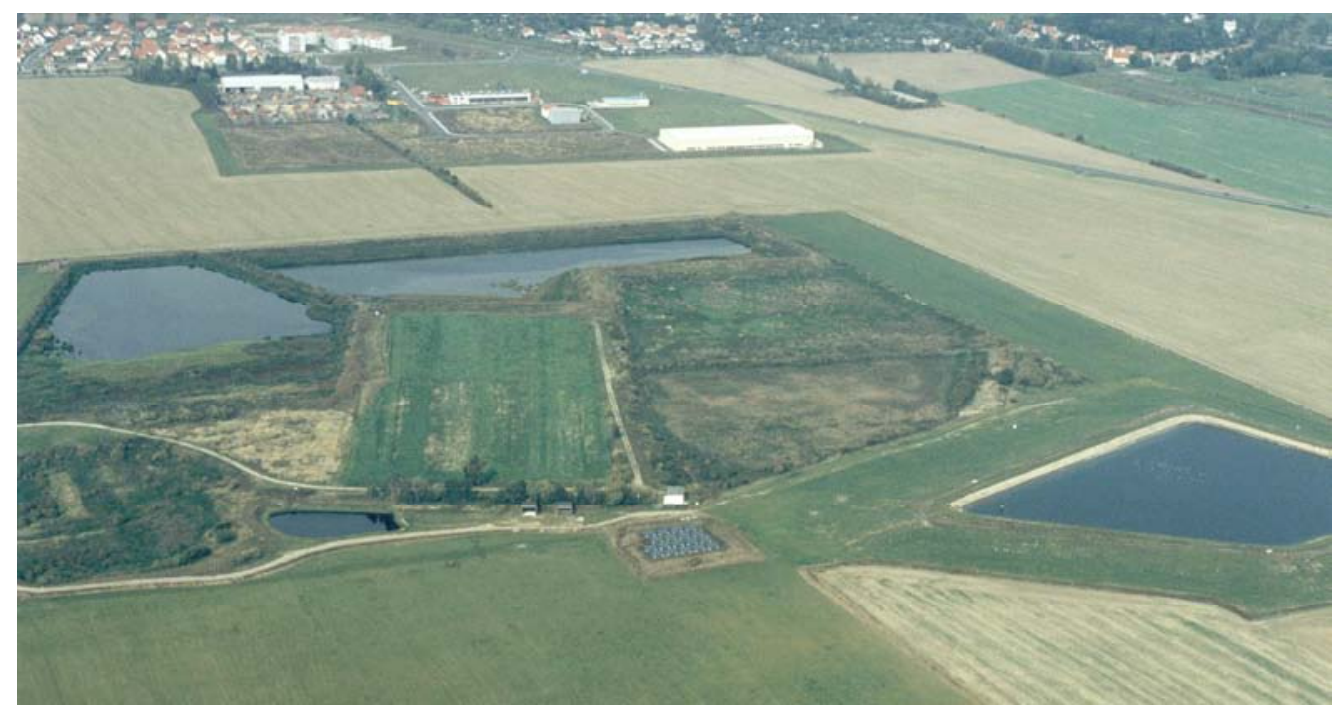

Fig 1. The site - Phytoremediation of a former sewage sludge deposit, Germany

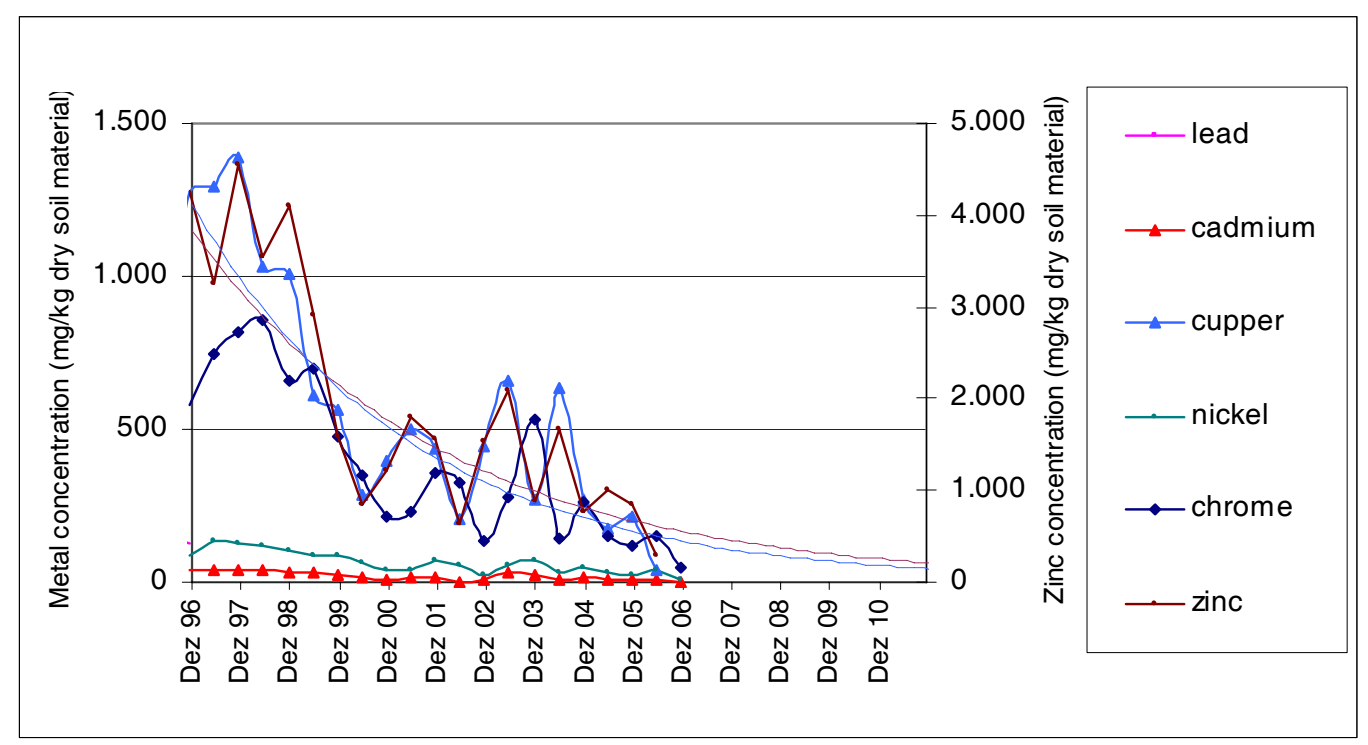

Fig 2. Results of Phragmites-based sludge decontamination 


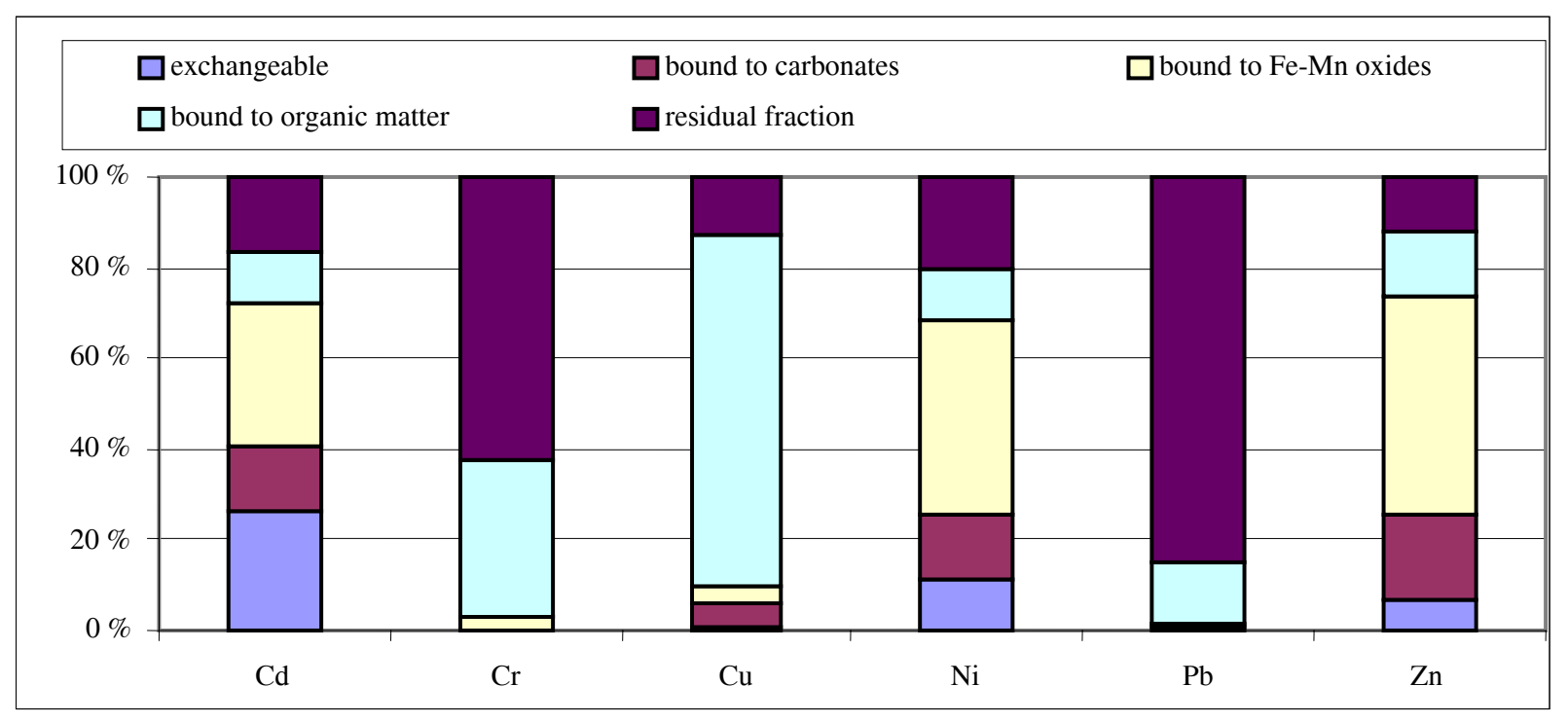

Fig 3. Distribution of heavy metals in soil fractions of sewage sludge

Simulating $100 \%$ bioavailability of soil contaminants in hydroponic solutions, a maximum of 4,000 ppm for $\mathrm{Cr}$ and $\mathrm{Cu}$ accumulation was found in roots, showing the potential for improved phytoextraction using common reed. However, plant vitality and survival was negatively affected by increased metal concentration in roots.

In a subsequent study, the use of different chelators has shown a dramatic increase of the metal mobility in soil substrate keeping metals as soluble chelate-metal complexes available for uptake into roots and transport within plants. For example, addition of EDTA (ethylenediamine-tetraacetic acid), at a rate of $10 \mathrm{mmol} / \mathrm{kg}$ sludge (dry weight), increased the total amount of $\mathrm{Cd}, \mathrm{Cu}, \mathrm{Ni}$ and $\mathrm{Zn}$ in soil solution. On the other hand, chrome and lead concentration in pore water was less affected by application of EDTA, NTA (nitrilotriacetic acid) and citric acid at concentrations of up to $10 \mathrm{mmol} / \mathrm{kg}$ sludge (dry weight).

Furthermore, soil column experiments (Fig 4) showed a significant increase in the metal content of $\mathrm{Cu}$, $\mathrm{Ni}$ and $\mathrm{Zn}$ in plant roots and shoots after metal mobilisation with 2 mmol EDTA per $\mathrm{kg}$ sludge. In addition, total metal analysis confirmed $\mathrm{Cu}, \mathrm{Ni}$ and $\mathrm{Zn}$ at a maximum of $30 \mathrm{mg}$ per litre in leachate, showing that chelate-assisted phytoextraction bears also the risk of metal leaching.

As shown in greenhouse experiments, the application of different natural plant tonics significantly influenced the aboveground biomass and root biomass of each plant, resulting in improved phytoextraction (factor 2 to 3 by application of the plant tonic Silpan to common reed) by increasing the root-shoot ratio.

In further experiments, BioPlanta has investigated the effect of crop maintenance practices on enhanced plant vitality and biomass production to improve phytoextraction on the multipolluted site. Irrigation may be required to achieve adequate soil moisture to solubilise metal and to maintain evapotranspiration. In field studies, increasing soil humidity by additional irrigation, common reed showed a significant increase of zinc content taken up from soil. Analogously, herbicide application before harvest resulted in an improved phytoextraction of $\mathrm{Cr}, \mathrm{Ni}$ and especially $\mathrm{Zn}$ by factor 2 to 3 in comparison to control plants due to enhanced transpiration.

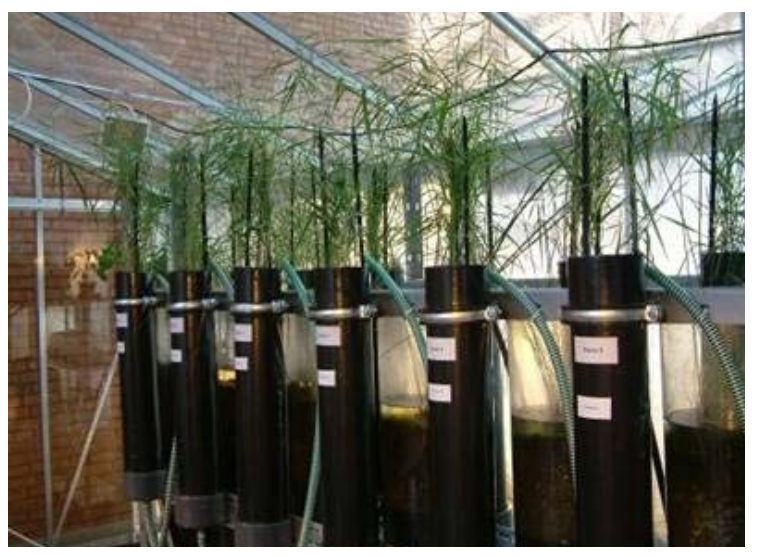

Fig 4. Leaching column experiment for investigating the mobilisation and plant uptake of metals by application of EDTA to soil

In field studies, BioPlanta proved, that after application of natural N-P-K fertiliser, particularly in the early stage of growth, common reed showed a significant twofold higher biomass ( $2 \mathrm{~kg}$ of dry weight per square metre) compared to control plants without additional nutrients, resulting in improved phytoextraction of $\mathrm{Ni}$ and $\mathrm{Zn}$ by factor 2 to 3 .

At maturity, the operation of phytoextraction depends on the periodical removal of contaminated biomass (Fig 5). The previous harvest of common reed in December yielded a site specific aboveground biomass at an average of $0.4 \mathrm{~kg}$ of dry weight per square metre. Increase in plant dry biomass was achieved by harvesting common reed in October and November. In contrast, multiple harvest of common reed within the growing season produced no further increase of plant dry biomass. 


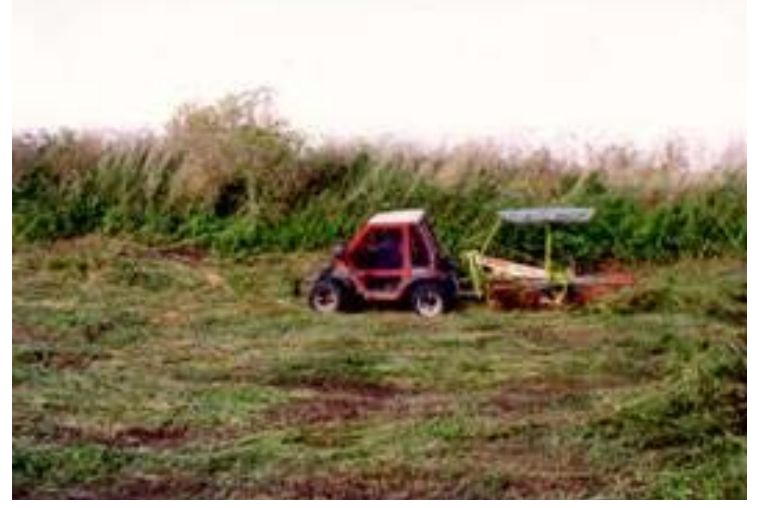

Fig 5. Harvest and disposal of heavy metal-containing biomass

Table 1. Heavy metal phytoextraction efficiency: comparison of different plant species

\begin{tabular}{|c|c|c|c|c|}
\hline \multirow[t]{2}{*}{ Metal } & \multicolumn{4}{|c|}{$\begin{array}{l}\text { Heavy metal removal by aboveground biomass } \\
{\left[\mathrm{mg} / \mathrm{m}^{2}\right]}\end{array}$} \\
\hline & maize & sunflower & rape & reed \\
\hline cadmium & 2,5 & 2,7 & 0,3 & 0,1 \\
\hline chrome & 1,6 & 0,9 & 2,3 & 0,4 \\
\hline cupper & 11,7 & 14,3 & 7,1 & 8,7 \\
\hline nickel & 1,6 & 6,7 & 1,4 & 1,4 \\
\hline lead & 1,7 & 1,1 & 3,9 & 0,4 \\
\hline zinc & 448,0 & 586,1 & 26,7 & 84,6 \\
\hline
\end{tabular}

With growing of several highly productive species at contaminated sludge sunflowers showed an increase in removal of $\mathrm{Cd}, \mathrm{Cu}, \mathrm{Ni}$ and $\mathrm{Zn}$ (factor 2 to 25 ) in comparison to reed (Table 1), whereas rape has been proven to bioconcentrate the highest metal levels of $\mathrm{Cr}$ and $\mathrm{Pb}$ up to $40 \mathrm{ppm}$. Maize accumulated more contaminants than reed and produced the largest biomass, but the total amount of metals taken up was lower than in sunflower and rape.

\section{Conclusion}

BioPlanta has clearly shown the feasibility of improving phytoextraction on a multipolluted site by application of agronomic practise. The selection of remediating plant species has been shown to be the most important factor affecting the extent of metal removal regarding the metal concentration in plants and the biomass. The aim of further investigations is to prove the theoretical increase in phytoextraction by factor up to 28 combining agronomic practises with selected plant species.

Statistical evaluation of the present results will be performed by a further increase in the range of experiments in field studies. However, the application of additives such as chelating agents and fertilisers will be acceptable after a preliminary verification of the environmental harmlessness and the economic proportionality.

\section{References}

1. LASAT, M. M. Phytoextraction of metals from contaminated soil: A review of plant/soil/metal interaction and assessment of pertinent agronomic issues. Journal of Hazardous Substance Research, 2000, 2, p 1-25.

2. TESSIER, A.; CAMPBELL, P.; BISSON, M. Sequential extraction procedure for the speciation of particulate trace metals. Anal Chem, 1979, 51, p 844-851.

\section{AGRONOMINIŲ PRIEMONIŲ TAIKYMAS, GERINANT FITOEKSTRAKCIJĄ IVAIRIAIS TERŠALAIS UŽTERŠTOSE VIETOSE}

\section{Claus, H. Dietze, A. Gerth, W. Grosser, A. Hebner}

\section{Santrauka}

Vykdydama bendrą tiriamaji projektą atliekant vandens tyrimus Leipcige BioPlanta optimizuoja fitoatkūrimo procesą. Ši fitotechnologija taikoma nuo 1996 metų ankstesnei iš nuotekų dumblo vandenį šalinančiai įrangai Šladice netoli Leipcigo (1 pav.). Uždarant ịrangą 1990 metais apie $300000 \mathrm{~m}^{3}$ dumblo, užteršto sunkiaisiais metalais ir angliavandeniliais, buvo sukaupta šiame sklype. Tai didžiausias tokio pobūdžio fitoatkūrimo projektas Europoje. Buvo sukurta plati monitoringo ir analizès programa siekiant ịvertinti atkūrimo eigą (iki 2012 metu). Sklypo tarša galèjo labai sumažèti. Sunkiujų metalų pašalinimas siekia daugiau kaip kelis kilogramus su didejjimo tendencija pastaraisiais metais (2 pav.). Tyrimo tikslas - sudaryti geresnes sąlygas dar efektyvesnei sunkiujų metalų jonų ekstrakcijai iš užteršto dirvožemio ir nuosėdų. Optimizuojant ši procesą atkūrimo laikotarpis turètų sutrumpèti iki dviejų trečdalių. Ši technologija turi būti igyvendinama ateityje vykdant atkūrimo projektus.

Reikšminiai žodžiai: fitoatkūrimas, metalų biogalimybès, augalų parinkimas, pasẻlių priežiūra, augalų biomasè. 
ПРИМЕНЕНИЕ АГРОНОМИЧЕСКИХ СРЕДСТВ ДЛЯ УЛУЧШЕНИЯ ФИТОЭКСТРАКЦИИ В МЕСТАХ, ЗАГРЯЗНЕННЫХ НЕСКОЛЬКИМИ ЗАГРЯЗНИТЕЛЯМИ

Д. Клаус, Г. Дитце, А. Герт, В. Гроссер, А. Гебнер

\section{Р е 3 ю м е}

В результате сотрудничества с самоуправлением Лейпцига в создании общего проекта исследований по вопросам водных работ «БиоПланта» оптимизирует процесс фиторемедиации. Эта фитотехнология применялась в Шладице около Лейпцига с 1996 г. в оборудовании по удалению воды из ила сточных вод (Рис. 1). После 1990 г., когда упомянутое оборудование перестало применяться, на участке было собрано $300000 \mathrm{~m}^{3}$ ила, загрязненного тяжелыми металлами и углеводородом. Это самый крупный проект фиторемедиации такого типа в Европе. Для оценки эффективности процесса восстановления до 2012 г. будет создана широкая программа мониторинга и анализа. Загрязнение этого места должно значительно уменьшиться. Загрязнение тяжелыми металлами составляет несколько килограммов, а в последние годы имеет тенденцию к увеличению (Рис. 2). Целью проводящихся исследований было создание лучших условий для более эффективной экстракции ионов тяжелых металлов из загрязненной почвы и осадков. В результате оптимизации этого процесса период восстановления должен уменьшиться. Названная технология должна быть внедрена в Лейпцигском регионе, а также внедряться в будущем при осуществлении восстановительных проектов.

Ключевые слова: фиторемедиация, биовозможности металлов, подбор растений, уход за посевами, биомасса растений. 